\title{
MARKET STRUCTURE AND PROFITABILITY: EVIDENCE IN THE INDONESIAN ISLAMIC INSURANCE INDUSTRY
}

\author{
Mohammad Nur Rianto Al Arif* \\ Universitas Islam Negeri (UIN) Syarif Hidayatullah Jakarta, Indonesia \\ Bella Firmansyah \\ Universitas Islam Negeri (UIN) Syarif Hidayatullah Jakarta, Indonesia
}

\begin{abstract}
There is limited research about the relationship between market structure and profitability in the insurance industry, especially in the Islamic insurance industry. This study examines the relationship among market structure and profitability in Islamic life insurance industry in Indonesia. This research used regression with panel data for the technique of analysis. The model used in this research was the fixed effect model. The result shows that the market structure affected the profitability of Islamic life insurance industry. This result implies that the traditional hypothesis supports the performance of Islamic life insurance industry in Indonesia. However, this research shows that there is no collusive behavior in Islamic life insurance industry in Indonesia. Meanwhile, for control variables, operational efficiency has an adverse effect on the performance of Islamic life insurance industry in Indonesia.
\end{abstract}

Keywords: Market Structure, Profitability, The Islamic Insurance Industry.

Received: 2 April 2019

Accepted: 10 May 2021

https://doi.org/10.33736/ijbs.3778.2021

\section{INTRODUCTION}

The insurance industry is one of the important elements in the financial system, including the Islamic insurance industry. Islamic insurance industry has developed quite rapidly in the world, including in Indonesia. Indonesia as one of the countries with the largest Muslim population has good potential for the development of the Islamic insurance industry. Although, there have been quite some studies that discuss the relationship between market structure and the level of profitability. However, most of the research related to the market structure in the financial industry has so far focused on the banking industry. The research on the relationship of market structures to performance in Islamic insurance companies especially is still limited. It is necessary to examine the industry's performance by measuring its profitability in a dual system where Islamic insurance companies are trading alongside with conventional players. This becomes interesting issue, because competition does not only occur with fellow Islamic insurance companies, but competition also occurs with conventional insurance companies.

* Corresponding author: Faculty of Economics and Business, Universitas Islam Negeri (UIN) Syarif Hidayatullah Jakarta, Jl. Ibnu Sina IV, South Tangerang, Banten, Tangerang; Tel: +62818118746; Email: nur.rianto@uinjkt.ac.id. 
Some studies had discuss the relationship between market structure on the performance in insurance industry, such as on the efficiency (Alhassan et al., 2015; Jaloudi \& Bakri, 2019; Alshammari et al., 2019); financial stability (Shim, 2015); profitability (Pope \& Ma, 2008; McShane et al., 2010; Njegomir \& Stojić, 2011; Basturk, 2012). The specific relationship shared by an insurance market's concentration to profitability has received far less attention. This study focus to look at how the relationship between market structure and company performance, where performance is measured by the level of profitability

Islamic insurance in Indonesia has proliferated. Islamic insurance business competition in Indonesia is increasingly crowding with the emergence of new players, both from life insurance and loss/general insurance with sharia principles. While Islamic reinsurance also undergoes a change in composition, namely from all companies that are only in the form of Islamic business units, there is one company in the form of sharia (full sharia) by spinning off. The increasing number of Islamic insurance companies will increase competition among them. Increasingly fierce competition will have an impact on company performance.

Table 1 shows the development of the Islamic insurance industry in Indonesia. The increase occurs in life insurance, general insurance, reinsurance and the Islamic business Unit itself. At the beginning of 2010, the number of Islamic Insurance in Indonesia was 43, and in 2017 this increased to 63. From 2010 to 2019 the number of Islamic Insurance increased by 20 Islamic Insurance companies. Although, in general, the market share of the Islamic insurance industry is still smaller than the Islamic banking industry.

Table 1: The Development of Islamic Insurance in Indonesia

\begin{tabular}{lccccccc}
\hline \multicolumn{1}{c}{ Companies } & $\mathbf{9 0 1 3}$ & $\mathbf{2 0 1 4}$ & $\mathbf{2 0 1 5}$ & $\mathbf{2 0 1 6}$ & $\mathbf{2 0 1 7}$ & $\mathbf{2 0 1 8}$ & $\mathbf{2 0 1 9}$ \\
\hline Islamic life insurance & $\mathbf{2 0 1 3}$ & 3 & 5 & 5 & 7 & 7 & 7 \\
Islamic life insurance - IBU & 17 & 18 & 19 & 20 & 23 & 23 & 23 \\
Islamic General Insurance & 2 & 2 & 3 & 4 & 5 & 5 & 5 \\
Islamic General Insurance -IBU & 24 & 23 & 25 & 24 & 25 & 24 & 24 \\
Islamic Reinsurenace & 0 & 0 & 0 & 1 & 1 & 1 & 1 \\
Islamic Reinsurance -IBU & 3 & 3 & 3 & 2 & 2 & 2 & 3 \\
\hline Total & $\mathbf{4 9}$ & $\mathbf{4 9}$ & $\mathbf{5 5}$ & $\mathbf{5 6}$ & $\mathbf{6 3}$ & $\mathbf{6 3}$ & $\mathbf{6 3}$ \\
Source: Financial Service Authority (OJK) & & & & & & & \\
*IBU = Islamic business units & & & & & &
\end{tabular}

Government regulations concerning minimum capital insurance, as well as plans of several Islamic insurance companies to conduct spin-offs following the laws and regulations concerning insurance. It can predict that up to the next years the number of Islamic insurance will continue to grow. 
Table 2: The Market Share and Herfindahl Hirschman Index in the Islamic Insurance Industry

\begin{tabular}{ccc}
\hline Year & Market Share & Herfindahl Hirschman Index \\
\hline 2012 & 3.81 & 1359.47 \\
2013 & 4.15 & 1506.6 \\
2014 & 5.07 & 1526.38 \\
2015 & 5.73 & 1732.8 \\
2016 & 6.60 & 1484.56 \\
2017 & 6.75 & 1537.45 \\
2018 & 6.91 & 1587.21 \\
2019 & 7.05 & 1612.31 \\
\hline
\end{tabular}

Source: Data Processed

Table 2 shows the development of the market share of the Islamic insurance industry in Indonesia from the aspect of total assets. The data indicates that the market share of Islamic insurance still has a small market share if we compared with the insurance industry as a whole. Besides, the data in Table 2 also shows the level of market concentration as measured by the Herfindahl Hirschman Index. Market concentration is one of the proxies of market structure. The data indicates that the market structure in the Islamic insurance industry included in the oligopoly market category. This condition is similar to the insurance market in Jordan that highly concentrated (Jaloudi \& Bakir, 2019).

In a perfect competition model, there are a large number of firms. The larger the number of firms, the higher the competition and lower the concentration ratio. The lower the concentration ratio, the lower the profit rates for a firm. In contrast, firms under an imperfect market will have significant market power, thus have control over the price of the product. The higher the concentration ratio by a firm, the economic profits will be higher too. The notion that there exists a relationship between market concentration and performance is a matter of empirical evidence.

This makes the study of the relationship between market structure and profitability in insurance still interesting to study. Therefore, this study addresses this gap by performing an earlier examination of the relationship shared by market concentration and profitability in the Islamic insurance industry. So, this research will make a significant contribution to research related to market structure and profitability in the Islamic insurance industry. Based on literature searches that have been carried out by researchers, there is still no study that examines the effect of market structure on profitability in the Islamic insurance industry. So that this study will make a significant contribution in the study of Islamic finance, especially the study of Islamic insurance.

The purpose of this study is to examine the relationship between market structure and profitability in the Islamic insurance industry. The paradigm used in this research to explain the experimental result from this research is the structure-conduct-performance (SCP) paradigm. The hypothesis that uses in this research is the traditional hypothesis that states market structure had a significant effect on the performance of the companies. 


\section{LITERATURE REVIEW}

This study uses the structure conduct performance (SCP) hypothesis to examine the impact of market structure on profitability in the Indonesian Islamic insurance companies. The use of the SCP hypothesis in assessing the effect of market structure on company performance is a common thing to do in the study of industrial organizations. SCP hypothesis is used because it is able to describe how much the market structure can affect the performance of the company.

The traditional SCP hypothesis based on the proposition: when a few firms have a large percentage of market shares, this impulse collusion among firms in the industry (Samad, 2008). The collusion behavior increases the market share concentration in the hands of a few firms. There is a positive relationship between market concentration and the company's' performance (Samad, 2008; Homma et al., 2014; Chan et al., 2015). The inverse relationship between the degree of concentration and the degree of competition was the underlying assumption of the SCP hypothesis (Jaloudi \& Bakir, 2019). Therefore, more concentrated companies will earn more profits than companies in less concentrated industries.

Most of the studies that discuss the relationship between market structure and company performance in the financial industry only focus on the banking industry. There are still a few studies that discuss the influence of market structure on performance in insurance companies, especially Islamic insurance companies. Joskow (1973) is one of the earliest researchers that had studied the SCP hypothesis in the insurance industry. The collusive behavior among insurers leads to the cuts in supply, inefficient sales systems, and over-capitalized industry (Joskow, 1973). Cole et al. (2015) conclude that there is a positive relationship between market concentration and insurer profits, but they unable to definitively determine if this result is due to anticompetitive behavior or greater efficiency from the insurer.

This SCP theoretical view subsequently was challenged by the efficient structure (ES) hypothesis. According to the ES hypothesis, efficient producing firms generate higher sales through lower pricing (Alhassan et al., 2015). The ES hypothesis stated that the relationship between concentration and performance is not due to corporate collusion, but rather is the result of the company's efficiency (Demsetz, 1973; Smirlock, 1985; Jaloudi \& Bakir, 2019). Eling and Jia (2019) find a positive relationship between the efficiency and profitability in the global insurance industry. Efficiency negatively correlates with insurer failure probability (Eling \& Jia, 2018).

Companies can improve the lower prices if they can help more efficient rather than their competitors. The more efficient the companies, it will allow them to get a larger share of the market with charge lower prices than competitors (Choi \& Weiss, 2005). The more efficient a company is, the more competitive advantage the company will make. This competitive advantage will have implications for increasing the market share of the company. The increased profits are supposed to return to the most efficient companies because of their efficiency and not because of their collusion activities as SCP suggests (Molyneux \& Forbes, 1995).

Alhassan et al. (2015) conclude that the efficiency structure (ES) hypothesis found either in life and non-life insurance markets. However, the SCP hypothesis only found in the non-life insurance market, and it rejected in the life insurance market. Jaloudi and Bakir (2019) conclude that the experimental result supported the SCP hypothesis in the insurance market in Jordan. However, the 
ES hypothesis was not supported in the insurance market in Jordan. Pope and Ma (2008) had done the research that includes 23 nations from 1996 to 2003. They found that the SCP hypothesis is supported when the levels of liberalization are low.

\section{METHODOLOGY}

The data used in this study comes from the companies' annual report. The data used is annual report starting from 2012 until 2019 from Islamic life insurance companies in Indonesia. The number of companies that became the object of this study is ten companies. The reason for using the data is due to the limitations of the data obtained. Only 10 of these companies have complete financial statements to be accessed from the 2012-2019 period.

This research using panel regression to examine the relationship between market structure and profitability in the Indonesian Islamic life insurance companies. The model that proposed in this research as follows:

$$
R O A_{i t}=\alpha+\beta_{1} M S_{i t}+\beta_{2} H H I_{t}+\beta_{3} M S_{i t} * H H I_{t}+\beta_{4} E f f_{i t}+\varepsilon_{i t}
$$

Where: ROA is profitability ratio; MS is market share of each Islamic life insurance; HHI is the market structure that proxied by Herfindahl Hirschman Index; MS*HHI is the interaction variables between market share and Herfindahl Hirschman Index; Eff is operational efficiency ratio.

There are some reasons why the ROA measure is preferable to other profit measures. First, although some studies have used product prices as the proxy of profits, but insurance is a multiproduct business and individual prices may be misleading. Second, the potential for significant cross-subsidisation between products obviously exists and princing strategy will differ across markets. The use of ROA will eliminate many of these problems and this proxy has been used extensively in the literature (Evanoff \& Fortier, 1988).

The technique of analysis to estimate the parameter of this research is by using a panel data regression. Several models can use, such as First, the pooled regression model. This model is one type of model that has constant coefficients, referring to both intercepts and slopes. For this model researchers can pool all of the data and run an ordinary least squares regression model. The second model is fixed effect model. The fixed effect model is the differences across cross-sectional units that can be captured in differences in the constant term and the intercept term of the regression model varies across the cross sectional units. In this model, $\alpha_{\mathrm{j}}$ is the intercept term that represents the fixed country effect. The third model is random effect model. In the random effect model, the individual effects are randomly distributed across the cross-sectional units and in order to capture the individual effects, the regression model is specified with an intercept term representing an overall constant term. On this research is using panel regression with fixed effect model, because we assume that the intercept is not constant (Hiestand, 2005).

There are several steps in this research, such as: first, run the estimation using the fixed-effect model. Second, do the Chow-test to choose between pooled ordinary least square or fixed effect models. Third, do the Breusch pagan LM test to select between random effect model or common 
effect models. Fourth, do the Hausman-test to select between fixed effect model and random effect model.

\section{RESULTS AND DISCUSSION}

There are three tests conducted to get the best model. First, we use Chow test to determine the best model between the pooled regression model and the fixed effect model. The test results show that we can reject the null hypothesis, so it can be said that intercepts are constant at $\mathrm{i}$ and $\mathrm{t}$, therefore the best model is the fixed effect model. Then, we do the Breusch Pagan LM test to test the best model between the random effect model and the pooled regression model. The test results show the null hypothesis is rejected, so the best model is the random effect model. Finally, we will test the Hausman test, this test is to find the best model between the fixed effect model and the random effect model. The test results show the null hypothesis is rejected, so it can be said that the best model is the fixed effect model. Based on these three tests, it can be concluded that the best model that can be used is the fixed effect model.

Table 3 shows the empirical result of this research. From Table 3 we can see that market share affected the profitability of the Islamic insurance companies. This result means that the higher the market share of a company, the greater the level of profit that can obtain. The market concentration variables that proxied by the Herfindahl Hirschman index show significant results. This result means that the more concentrated a market, the higher the level of profitability of a company. Large domestic companies with significant market shares in the local countries will have the opportunities to commence in business in other markets (Krishnamurthy et al., 2005). Insurance companies should diversify products to fulfill emerging needs in the market (Wu \& Wang, 2018). This action will lead to higher market shares for the companies.

Table 3. The Empirical Result

\begin{tabular}{lccc}
\hline \hline \multicolumn{1}{c}{ Variable } & PLS & FEM* & REM \\
\hline $\mathrm{C}$ & $29.80015^{*}$ & 3.475844 & $29.80015^{*}$ \\
& $(9.423811)$ & $(21.01123)$ & $(8.401919)$ \\
$\mathrm{MS}$ & $-1.723137 * * *$ & $-1.723137 * *$ & 2.269773 \\
& $(0.958387)$ & $(0.854462)$ & $(3.930970)$ \\
$\mathrm{HHI}$ & $0.013817^{* *}$ & $0.013817 * *$ & 0.008599 \\
& $(0.006359)$ & $(0.005670)$ & $(0.007446)$ \\
MSHHI & $0.001681 * *$ & $0.001681 * *$ & 0.000425 \\
& $(0.000632)$ & $(0.000564)$ & $(0.001299)$ \\
BOPO & $-0.076941^{*}$ & $-0.076941 *$ & -0.009168 \\
& $(0.011306)$ & $(0.010080)$ & $0.0026237)$ \\
\hline Adjusted R-square & 0,649013 & 0.795025 & 0,67765 \\
F-statistic & 24.43213 & 12.62401 & 0,000000 \\
Prob. (F-statistic) & 0,000000 & 0.00000 & \\
Source: Data processed & & & \\
Note: significant in $* 1 \% ; * 5 \% ; * * * 10 \%$. & &
\end{tabular}

The interaction variables between market share and market concentration show significant results. These results indicate that the market structure has an impact on the profitability of a company. 
The more concentrated a market is, the greater the potential to obtain a higher level of profitability. The last variable for the control variable from this model is the operational efficiency ratio. The result shows that the operational efficiency ratio affected profitability. The more efficient a company is, the higher the level of profitability will be.

The adjusted r-square value of 0.7950 shows the coefficient of determination. This result shows that the variables that have been able to explain the model is $79.50 \%$, and other variables outside the model explain the rest. Finally, the F-statistic value shows how much the independent variable is capable of influencing the dependent variable. The F-test results show that all independent variables simultaneously affect the dependent variable.

This study found that there is a relationship between market structure and the performance -proxied by profitability- of the Islamic life insurance companies. This research is consistent with the traditional hypothesis that commonly used in the structure-conduct-performance (SCP) paradigm. The traditional hypothesis states that the more concentrated a market structure (the greate of the market power) will cause a company to increases its profits (Evanoff \& Fortier, 1988; Molyneux \& Forbes, 1995; Celik \& Kaplan, 2016; Stanciulescu \& Molnar, 2017).

Besides that, this research also consistent with Bajtelsmit and Bouzouita (1998), Pilloff and Rhoades (2002), Molyneux and Forbes (1995), Hamid (2017), and Jaloudi and Bakir (2019) that found the relationship between market structure and profitability. Martin (2012) found that the more competitive market structures accompany the better performance. Competition will increase the soundness of insurance market (Cummins et al., 2017). Pope and Ma (2008) and Njegomir and Stojic (2011) found that the interaction of market liberalization and market concentration shares a complicated relationship with market profitability. Acosta (2014) state that there is a negative relationship between the insurance market concentration and insurance coverage. Alshammari et al. (2019) concludes that there are differences in results between the conventional insurance industry and the Islamic insurance industry related to the relationship between competition and efficiency. The relationship between competition and efficiency turns out to be negative for the conventional insurance, and positive only for Islamic insurance.

Besides that, Choi and Weiss (2005) and Alhassan et al. (2015) found that the Efficiency structure (ES) hypothesis had proven for insurance markets. The ES hypothesis posits that more efficient firms can charge lower prices than competitors, enabling them to capture larger market shares and economic rents, leading to increased concentration. Consumer expenditures can be one of the factors that can lead a firm efficiency (Tan et al., 2009). The level of efficiency resulting from fair competition will contribute to insurer solvency (Cummins et al, 2017). Low concentration levels as a result of high competition between insurance companies (Cãpraru \& Moise, 2015). Insurance companies should do a strategic action to increase the efficiency. This action based on the study from Karbhari et al. (2018) that found the insurance companies are inefficient because the widespread managerial lethargy and operational inefficiency.

In other perspective, Feo and Hindriks (2014) show that competition can be worse under competition rather than under monopoly. Monopoly can exploit its market power to relax incentives constraints by cross-subsidization between different risk types. Basturk (2012) observed that the competitive structure and competition reflected negatively into the company's profitability. This result is different from Samad (2008), Seelanatha (2010), Mensi and Zouari (2011), Martin 
(2012), and Yuhanah (2016). Samad (2008) and Yuhanah (2016) conclude that there is no relationship between market structure and profitability.

This result shows that the government must be able to show an excellent competitive climate. A stable political environment will drive a less risk-taking for insurer (Lee \& Lin, 2016). Hidayat and Firmansyah (2017) state that Islamic insurance industry should strengthen the ownership structure. Besides that, one of the things to note regarding the competitive climate in the Islamic insurance industry is the issuance of law number 40 of 2014 concerning insurance. In the law, it is stated that every Islamic business unit is obliged to spin-off from its parent company if it has fulfilled the criteria or in 2024. This policy raises the potential for many Islamic insurance companies to merge or even close their businesses. This activity will make the Islamic insurance industry more concentrated than before.

Besides that, Wu and Wang (2018) propose some policy to improve corporate performance. First, life insurance companies should reinforce the dominance of banks. Second, life insurance companies ought to exploit online channels. Third, life insurance companies must diversify product to fulfill consumer needs. Krivokapic et al. (2017) also conclude that there is a relationship between line-of-business diversification and performance for the insurance companies. Fourth, life insurance should increase compensation rate. Finally, the Islamic insurance companies can use market, product, and process innovations as the strategies appropriate to expand the market (Nugraheni \& Muhammad, 2020).

\section{CONCLUSION}

The purpose of this study is to examine the relationship between the market structure and profitability in the Indonesian Islamic insurance industry. The result shows that the market structure affected the profitability of the Islamic insurance industry. This result implies that the more concentrated the industry, the higher the level of profitability. The result of this research is to support the traditional hypothesis that commonly uses in the structure-conduct-performance (SCP) hypothesis.

Several recommendations can offer for the regulator and Islamic insurance companies. First, the regulator must prepare policies that support the acceleration of Islamic insurance growth. Second, conventional parent insurance must prepare its Islamic business unit regarding the spin-off obligation. The spin-off activities must be prepared carefully because this will have an impact after the spin-off activity is carried out. Third, there needs to be a synergy of policies in Islamic financial institutions to accelerate its growth.

\section{REFERENCES}

Acosta, R. S. (2014). Effects of Health Insurance Concentration Market on Insurance Coverage in Colombia. Journal of Competitiveness, 6(3), 3-19. https//doi.org/10.7441.joc.2014.03.01

Alhassan, A. L., Addison, G. K., \& Asamoah, M. E. (2015). Market Structure, Efficiency, and Profitability of Insurance Companies in Ghana. International Journal of Emerging Markets, 10(4), 648-669. https//doi.org/10.1108/IJoEM-06-2014-0173 
Alshammari, A. A., Alhabshi, S. M. S. J., \& Siti, B. (2019). The Impact of Competition on Cost Efficieny of Insurance and Takaful Sectors: Evidence from GCC Markets Based on the Stochastics Frontier Analysis. Research in International Business and Finance, 47, 410427. https//doi.org/10.1016/j.ribaf.2018.09.003

Bajtelsmit, V. L., \& Bouzouita, R. (1998). Market Structure and Performance in Private Passenger Automobile Insurance. The Journal of Risk and Insurance, 65(3), 503-514.

Basturk, F. H. (2012). Characteristics and Competition Structure of Turkish Insurance Industry. Procedia -Social and Behavioral Sciences, 62, 1084-1088. https//doi.org/10.1016/i.sbspro.2012.09.185.

Cãpraru, B., \& Moise, N. (2015). Insurance Market's Competition in Romania After 2007. Procedia Economics and Finance, 20, 112-118. https//doi.org/10.1016/S22125671(15)00054-4

Celik, T., \& Kaplan, M. (2016). Testing The Structure-Conduct-Performance Paradigm for The Turkish Banking Sector: 2008-2013. International Journal of Economics and Financial Issues, 6(4), 1625-1631.

Chan, S. G., Koh, E. H. Y., Zainir, F., \& Yong, C. C. (2015). Market Structure, Institutional Framework and Bank Efficiency in ASEAN 5. Journal of Economics and Business, 82, 84112. https//doi.org/10.1016/j.jeconbus.2015.07.002.

Choi, B. P., \& Weiss, M. A. (2005). An Empirical Investigation of Market Structure, Efficiency, and Performance in Property-Liability Insurance. Journal of Risk and Insurance, 72(4), 635-673. https//doi.org/10.1111/j.1539-6975.2005.00142.x.

Cole, C. R., He, E., \& Karl, J. B. (2015). Market Structure and the Profitability of US Health Insurance Marketplace: A State Level Analysis. Journal of Insurance Regulation, 34(1), 130 .

Cummins, J. D., Rubio-Misas, M., \& Vencappa, D. (2017). Competition, Efficiency and Soundness in European Life Insurance Markets. Journal of Financial Stability, 28, 66-78. https//doi.org/10.1016/j.jfs.2016/11.007.

Demsetz, H. (1973). Industry Structure, Market Rivalry, and Public Policy. Journal of Law and Economics, 16, 1-9.

Eling, M., \& Jia, R. (2018). Business Failure, Efficiency, and Volatility: Evidence from the European Insurance Industry. International Review of Financial Analysis, 59, 58-76. https//doi.org/10.1016/j.irfa.2018.07.007.

Eling, M., \& Jia, R. (2019). Efficiency and Profitability in the Global Insurance Industry. Pacific Basin Finance Journal, 57, 1-12. https//doi.org/10.1016/j.pacfin.2019. 101190.

Evanoff, D. D., \& Fortier, D. L. (1988). Reevaluation of the Structure-Conduct-Performance Paradigm in Banking. Journal of Financial Services Research, 1(3), 277-294. https//doi.org/10.1007/BF00114854.

Feo, G. D., \& Hindriks, J. (2014). Harmful Competition in Insurance Market. Journal of Economic Behavior and Organization, 106, 213-226. https//doi.org/10.1016/j.jebo. 2014.06.002.

Hamid, F. S. (2017). The Effect of Market Structure on Bank's Profitability and Stability: Evidence from ASEAN-5 Countries. International Economic Journal, 31(4), 575-598. d https//doi.org/10.1080/10168737.2017.1408668.

Hidayat, I. P., \& Firmansyah, I. (2017). Determinants of Financial Performance in the Indonesian Islamic Insurance Industry. Etikonomi, 16(1), 1-12. https//doi.org/10.15408/etk.v16i1.4648.

Hiestand, T. (2005). Using Pooled Model, Random Model, and Fixed Model Multiple Regression to Measure Foreign Direct Investment in Taiwan. International Business \& Economics Research Journal, 4(12), 37-52. 
Homma, T., Tsutsui, Y., \& Uchida, H. (2014). Firm Growth and Efficiency in the Banking Industry. Journal of Banking and Finance, 40(March), 143-153. https//doi.org/10.1016/j.jbankfin.2013.11.031

Jaloudi, M., \& Bakir, A. (2019). Market Structure, Efficiency, and Performance of Jordan Insurance Market. International Journal of Business and Economics Research, 8(1), 6-13. https//doi.org/10.11648/j.ijber.20190801.12

Joskow, P. L. (1973). Cartels, Competition, and Regulation in The property-liability Insurance Industry. The Bell Journal of Economics and Management Sciences, 4(2), 375-427.

Karbhari, Y., Muye, I., Hassan, A. F. S., \& Elnahass, M. (2018). Governance Mechanisms and Efficiency: Evidence from an Alternative Insurance (Takaful) Market. Journal of International Financial Markets, Institutions, and Money, 56, 71-92. https//doi.org/10.1016/j.intfin.2018.02.017

Krishnamurthy, S., Mony, S. V., Jhaveri, N., Bakhshi, S., Bhat, R., Dixit, M. R., Maheshwari, S., \& Bhat, R. (2005). Insurance Industry in India: Structure, Performance and Future Challenges. Vikalpa: The Journal for Decision Makers, 30(3), 93-120. https//doi.org/10.1177/0256090920050308

Krivokapic, R., Njegomir, V., \& Stojic, D. (2017). Effects of Corporate Diversification on Firm Performance: Evidence from the Serbian Insurance Industry. Economic ResearchEkonomska Istrazivanja, 30(1), 1224-1236. https//doi.org/10.1080/1331677 X.2017.1340175

Lee, C-C., \& Lin, C-W. (2016). Globalization, Political Institutions, Financial Liberalization, and Performance of the Insurance Industry. The North American Journal of Economics and Finance, 36, 244-266. https//doi.org/10.1016/j.najef. 2016.01.007.

Martin, S. (2012). Market Structure and Market Performance. Review of Industrial Organization, 40(2), 87-108. https//doi.org/10.1007/s11151-012-9338-8.

McShane, M. K., Cox, L. A., \& Butler, R. J. (2010). Regulatory Competition and Forbearance: Evidence from the Life Insurance Industry. Journal of Banking and Finance, 34(3), 522532. https//doi.org/10.1016/j.jbankfin.2009.08.016.

Mensi, S. \& Zouari, A. (2011). Banking Industry, Market Structure, and Efficiency: The Revisited Model to Intermediary Hypotheses. International Journal of Economic Research, 2(1), 2336.

Molyneux, P., \& Forbes, W. (1995). Market Structure and Performance in European Banking. Journal Applied Economics, 27(2), 155-159. https//doi.org/10.1080/00036849500000018.

Njegomir, V., \& Stojic, D. (2011). Liberalisation and Market Concentration Impact on Performance of the Non-Life Insurance Industry: The Evidence from Eastern Europe. The Geneva Papers, 36, 94-106. https//doi.org/10.1057/gpp.2010.32.

Nugraheni, P., \& Muhammad, R. (2020). Innovation in the Takaful Industry: a Strategy to Expand the Takaful Market in Indonesia. Journal of Islamic Marketing, 11(6), 1313-1326. https//doi.org/10.1108/JIMA-08-2018-0143.

Pilloff, S. J., \& Rhoades, S. A. (2002). Structure and Profitability in Banking Markets. Review of Industrial Organization, 20(1), 81-98. https//doi.org/10.1023/A:1013362913973.

Pope, N., \& Ma, Y-L. (2008). The Market Structure-Performance Relationship in The International Insurance Sector. The Journal of Risk and Insurance, 75(4), 947-966.

Samad, A. (2008). Market Structure, Conduct and Performance: Evidence from The Bangladesh Banking Industry. Journal of Asian Economics, 19(2), 181-193. https//doi.org/10.1016/j.asieco.2007.12.007. 
Seelanatha, L. (2010). Market Structure, Efficiency, and Performance of Banking Industry in Sri Lanka. Banks and Bank System, 5(1), 20-31.

Shim, J. (2015). An Investigation of Market Concentration and Financial Stability in PropertyLiability Insurance Industry. Journal of Risk and Insurance, 84(2), 567-597. https//doi.org/10.1111/jori.12091.

Smirlock, M. (1985). Evidence on the (Non) Relationship Between Concentration and Profitability in Banking. Journal of Money, Credit, and Banking, 17(1), 69-83.

Stanciulescu, G. C., \& Molnar, E. I. (2017). Structure, Conduct, Performance Paradigm in Assessing Travel Agency Performances. Proceeding of the $11^{\text {th }}$ International Conference on Business Excellence: pp. 802-809. https//doi.org/10.1515/picbe-2017-0085.

Tan, H-B., Wong, M-F., \& Law, S-H. (2009). The Effect of Consumer Factors and Firm Efficiency on Malaysian Life Insurance Expenditure. International Journal of Business and Society, 10(1), 59-73.

Wu, M., \& Wang, Y. (2018). Influencing Factors of Corporate Performance of Life Insurance Companies: Evidence from China. Accounting and Finance Research, 7(2), 219-231. https://doi.org/10.5430/afr.v7n2p219.

Yuhanah, S. (2016). Pengaruh Struktur Pasar Terhadap Profitabilitas Perbankan Syariah di Indonesia. Esensi: Jurnal Bisnis dan Manajemen, 6(1), 125-138. https//doi.org/10.15408/ess.v6i1.3138. 